\title{
P229: Bacterial flora in burns patients at a tertiary care referral centre in North India
}

\author{
S Appannanavar ${ }^{1 *}$, N Taneja ${ }^{1}$, G Singh ${ }^{1}$, M Biswal $^{1}$, PS Chari², B Mohan ${ }^{1}$ \\ From 2nd International Conference on Prevention and Infection Control (ICPIC 2013) \\ Geneva, Switzerland. 25-28 June 2013
}

\section{Introduction}

Bacterial flora in burn patients undergoes a change over a period of time and is dependent upon many factors. Study of burn flora is not only helpful in locating entry of multidrug resistant bacterial strains into the unit's usual flora but also in determining current antibiotic susceptibilities.

\section{Objectives}

Since no studies are available from India to date that have studied sequential emergence of different microorganisms in burn wound, present study was carried out to study the evolution of bacterial flora in burn wounds and its correlation with invasive wound infection.

\section{Methods}

Patients with $20-70 \%$ of total burn surface were enrolled and followed up for their entire duration of stay . Clinical \& treatment details were noted. Surface wound swabs were collected on first, third, seventh, tenth and fourteenth day post admission. CDC case definitions were used to define invasive wound infections. Environmental sampling was done every three months.

\section{Results}

Of 215 wound swabs collected from 71 patients, 72 were sterile and 143 yielded 214 isolates. Colonization rates were $33 \%$ on first day, $94 \%$ on $7^{\text {th }}$ day and $100 \%$ by $14^{\text {th }}$ day. $42 \%$ swabs grew gram negative bacteria. Overall Staphylococcus aureus was the predominant isolate (45\%) followed by Pseudomonas aeruginosa (13.9\%), beta hemolytic Streptococci (9.4\%). Maximum invasive infections were seen at the seventh day. A high level of environmental contamination was seen with $S$. aureus, a substantial portion being MRSA.

${ }^{1}$ Medical Microbiology, Pgimer, Chandigarh, India

Full list of author information is available at the end of the article

\section{Conclusion}

Better control of environmental contamination and disinfection along with rigorous hand washing and barrier precautions are recommended to prevent infection of wounds.

\section{Disclosure of interest}

None declared.

\section{Author details}

${ }^{1}$ Medical Microbiology, Pgimer, Chandigarh, India. ${ }^{2}$ Plastic Surgery and Burn Unit, Pgimer, Chandigarh, India.

Published: 20 June 2013

\section{doi:10.1186/2047-2994-2-S1-P229}

Cite this article as: Appannanavar et al.: P229: Bacterial flora in burns patients at a tertiary care referral centre in North India. Antimicrobial Resistance and Infection Control 2013 2(Suppl 1):P229.

\section{Submit your next manuscript to BioMed Central and take full advantage of: \\ - Convenient online submission \\ - Thorough peer review \\ - No space constraints or color figure charges \\ - Immediate publication on acceptance \\ - Inclusion in PubMed, CAS, Scopus and Google Scholar \\ - Research which is freely available for redistribution

